TRABAJOS ORIGINALES

\title{
Notes on Halicyclops (Copepoda, Cyclopoida, Cyclopidae) from Colombia and the wes- tern Caribbean: a new record with a key to species of Group "B” sensu Rocha (1991)
}

\section{Notas sobre Halicyclops (Copepoda, Cyclopoida, Cyclopidae) de Colombia y el Caribe occiden- tal: un nuevo registro con una clave para las especies del Grupo "B" sensu Rocha (1991)}

\section{Juan M. Fuentes-Reinés ${ }^{1 *}$ and Eduardo Suárez-Morales ${ }^{2}$}

\author{
1 Universidad del Magdalena, Grupo de Investigación en Biodiversidad y Ecología Aplicada, A. A. 731 Santa Marta, Colombia \\ 2 El Colegio de la Frontera Sur, Unidad Chetumal, A.P. 424, 77014 Chetumal, Quintana Roo, México \\ * Corresponding author. \\ Email Juan M. Fuentes: juanfuentesreines@gmail.com \\ Email Eduardo Suárez: esuarez@ecosur.mx
}

\begin{abstract}
Three species of brackish waters microcrustaceans are herein recorded; they belong to the cyclopoid copepod genus Halicyclops and were collected from a coastal system in northern Colombia: $H$. exiguus Kiefer, 1934 $H$. venezuelaensis Lindberg, 1954, and $H$. hurlberti Rocha, 1991. The former has intraspecific variations that deserve further study. The finding of the latter species, previously known from the Eastern Tropical Pacific, represents a new record for Colombia and the Caribbean Sea Basin in the Northwestern Tropical Atlantic. With the finding of $H$. hurlberti the number of species of Halicyclops known from the Neotropical region and Colombia increases to 20 and 5 , respectively. The regional diversity of the genus is probably underestimated. A key to species of the genus belonging to group "B" sensu Rocha (1991) is also provided.
\end{abstract}

Keywords: Halicyclops; Caribbean Sea; distribution; brackish water crustaceans; taxonomy.

\section{Resumen}

Se registran tres especies de microcrustáceos de aguas salobres; son copépodos ciclopoides del género Halicyclops procedentes de un sistema costero en el norte de Colombia: $H$. exiguus Kiefer, 1934, H. venezuelaensis Lindberg, 1954 y H. hurlberti Rocha, 1991. La primera especie tiene una variación intraespecífica que merece estudios más profundos. El hallazgo de la última especie es conocida sólo en el Pacífico Tropical Oriental, representa un registro nuevo para Colombia y la cuenca del Mar Caribe en el Atlántico tropical noroccidental. Con el hallazgo de $\mathrm{H}$. hurlberti, la cantidad de especies de Halicyclops reconocidas en la región Neotropical y Colombia aumenta a 20 y 5 , respectivamente. La diversidad regional del género probablemente está subestimada. Se proporciona una clave para las especies del género que pertenecen al grupo "B" sensu Rocha (1991).

Palabras claves: Halicyclops; Mar Caribe; distribución; crustáceos de aguas salobres; taxonomía.

Citation:

Fuentes-Reinés J.M. \& E. Suárez-Morales. 2018. Notes on Halicyclops (Copepoda, Cyclopoida, Cyclopidae) from Colombia and the western Caribbean: a new record with a key to species of Group "B" sensu Rocha (1991). Revista peruana de biología 25(2): 141 - 146 (Mayo 2018). doi: http://dx.doi.org/10.15381/rpb.v25i2.14688

$\begin{array}{ll}\text { Received: } & 06 / 12 / 2017 \\ \text { Accepted: } & 26 / 02 / 2018\end{array}$

Published online: $30 / 05 / 2018$
Author contributions. JFR collected the samples; JFR and ES identified the specimens, JFR and ES wrote the text.

Conflict of interest. The authors declare that they have no conflict of interest. 


\section{Introduction}

The cyclopoid copepod Halicyclops is a cosmopolitan genus represented by free-living planktonic forms (Chang 2012, Ueda and Nagai 2012); members of this genus dwell in a wide range of habitats, having been recorded from shallow coastal environments, including brackish coastal habitats and estuaries (Suárez-Morales and Fuentes-Reinés 2014, Fuentes-Reinés and Suárez-Morales 2015), salt marshes (Chang 2012), anchialine caves (Rocha et al. 2000), inland waters with increased salinity (Karanovic 2004), and fresh water (Rocha 1995a, Defaye \& Dussart 1988, Fuentes-Reinés et al. 2013, Luong 2016). A few species are known to live loosely associated with benthic invertebrates (Humes 1947).

According to Walter and Boxshall (2017) the genus currently contains 99 valid species and 13 subspecies, but the genus is in need of revision. In the Neotropical region 19 valid species have been recorded (Rocha 1995a, Rocha et al. 1998, Suárez-Morales and Fuentes-Reinés 2014). Of these, only three species are hitherto known from Colombia: H. venezuelaensis Lindberg, 1954, $H$. exiguus Kiefer, 1934, and the recently described $H$. gaviriai Suárez-Morales and Fuentes-Reinés 2014. The first species is known from Ciénaga Grande de Santa Marta, Magdalena and Laguna Navío Quebrado (Fuentes-Reinés et al. 2013, FuentesReinés and Suárez-Morales 2015) whereas the other two only from the Laguna Navío Quebrado, La Guajira, (Suárez-Morales and Fuentes-Reinés 2014, Fuentes-Reinés and Suárez-Morales 2015).

During a survey of the plankton community of the Ciénaga Grande de Santa Marta, in the Colombian coast of the Caribbean, three species of the genus Halicyclops were collected: $H$. exiguus, $H$. venezuelaensis, and $H$. hurlberti Rocha, 1991 . The aim of this paper is to provide additional morphologic data of these taxa and report the first occurrence of the latter species in the Caribbean. A key to the species of the genus (sensu Rocha, 1991) including $H$. hurlberti, is also provided.

\section{Material and methods}

Plankton samples were taken monthly from the Ciénaga Grande de Santa Marta, Colombia (1052’11.25”N; $74^{\circ} 19^{\prime} 31.64$ ”W) from January to October 2017, mainly in the littoral areas with vegetation (mangrove) but also from open water. One thousand nine hundred forty-four (1944) liters of water were taken using a bucket of $25 \mathrm{~L}$, filtered with a zooplankton net $(45 \mu \mathrm{m})$, and preserved in $70 \%$ ethanol.

Water salinity was measured with a WTW 3111 conductivity meter. Copepods were sorted from the original samples and then processed for taxonomical identification. Dissected specimens and appendages were mounted in glycerine and sealed with Canada balsam. Digital photographs were taken using a Kodak Easy Share C140 camera attached to a compound Olympus CX22 microscope. The specimens were measured in lateral position, from the anterior end of the rostral area to the posterior margin of the caudal ramus.

The specimens examined were deposited at the Museo de Colecciones Biológicas at the Universidad del Atlántico (UARC), Colombia. Morphological terminology follows Huys and Boxshall (1991). The following abbreviations are used in the descriptive section: $\mathrm{P} 1-\mathrm{P} 6=$ first to sixth swimming legs, $\mathrm{EXP}=$ exopod, $\mathrm{ENP}=$ endopod, aps = apical seta, ins= Inner seta, Fig = Figure, UARC = Universidad del Atlántico Región
Caribe, $\mu \mathrm{m}=$ micron

\section{Taxonomy}

ORDER CYCLOPOIDA BURMEISTER, 1834
FAMILY CYCLOPIDAE DANA, 1846
SUBFAMILY HALICYCLOPINAE KIEFER, 1927
GENUS HALICYCLOPS NORMAN, 1903

Halicyclops exiguus Kiefer, 1934

Figures 1A-E

Material examined. Three adult females (UARC359-367M), Ciénaga Grande de Santa Marta, Colombia, coll. J.M. Fuentes Reinés.

Remarks. The specimens from Colombia share the diagnostic features from specimens of $H$. exiguus previously reported from the adjacent Guajira department in Colombia (Fuentes-Reinés and Suárez-Morales 2015). Body robust, compact anteriorly (Fig. 1A). Body length, excluding caudal setae $490 \mu \mathrm{m}(n=3)$. This species can be easily separated from its congeners by a combination of the following characteristics that are present in our specimens: 1) last segment of antenna with five lateral setae (arrows in Fig. 1B), length/wide ratio about 3.0 (Fig. 1B), 2) fourth segment of female antennule less than twice as long as wide (Fig. 1C), 3) female P5 exopod elongate, inner spine (ins) and apical seta (aps) as long as or longer than the segment (Fig. 1D), 4) Inner basipodal spine of P1 (arrow in Fig. 1E) reaching at least midlength of third endopod of $\mathrm{P} 1,5) \mathrm{P} 4 \mathrm{ENP} 3$
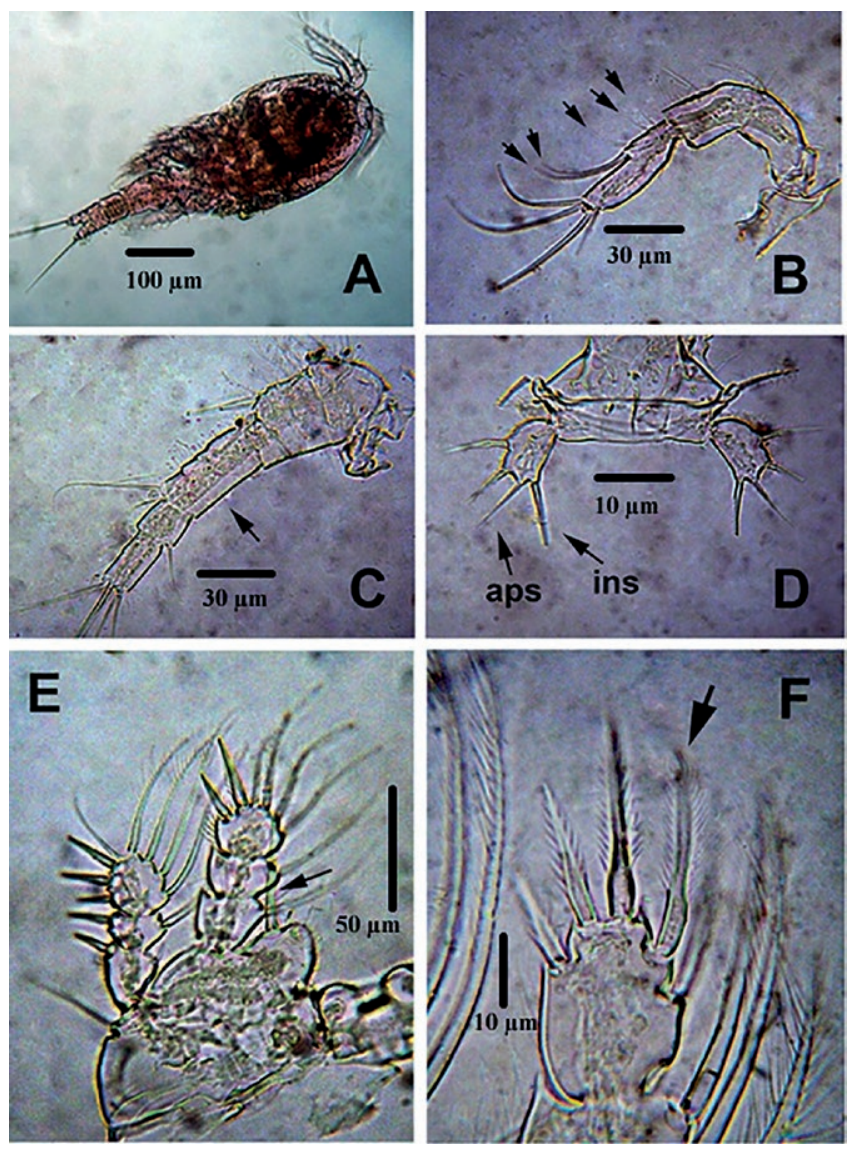

Figure 1. Halicyclops exiguus, Female. A. Habitus, B. Antenna, C. Antennule, D. P5. E. P1. F. P4ENP3 
with proximal inner seta (arrow in Fig. 1F) not reaching tip of inner apical spine.

In the specimens from Santa Marta examined the inner proximal seta of $\mathrm{P} 4 \mathrm{ENP} 3$ does not reach beyond the apical inner seta (Fig. 1F), but in the specimens reported by Kiefer (1934, Abb. 3) from Haiti, Collado et al. (1984, fig. 7) from Costa Rica, and Fuentes-Reinés and Suárez-Morales (2015, fig. 2e) from another Colombian locale, the inner proximal seta of P4ENP3 does reach beyond the apical element. This character appears to be variable in the species.

Distribution. Hitherto, this species has been recorded only from the Neotropical region; it has been reported in Haiti (Kiefer 1934) (but see Rocha et al. 1998), Costa Rica (Collado et al. 1984), French Guiana (Defaye and Dussart 1988), and Brazil (Rocha and Iliffe 1993). In Colombia this species has been reported in La Guajira department (Fuentes-Reinés-SuárezMorales 2015); the present record represents a modest range expansion in the country, which now includes the Magdalena Department. It is also the second record of the species in the Caribbean coast of Colombia.

\section{Halicyclops venezuelaensis Lindberg, 1954}

$$
\text { (Figs 2A-D, 3A, B) }
$$

Material examined. One adult female (UARC353-358M), Ciénaga Grande de Santa Marta, Colombia, coll. J.M. Fuentes Reinés.

Remarks. The specimen examined bears the diagnostic features of $H$. venezuelaensis as described by Lindberg (1954), Rocha (1995b) and Fuentes-Reinés et al. (2013). Body robust
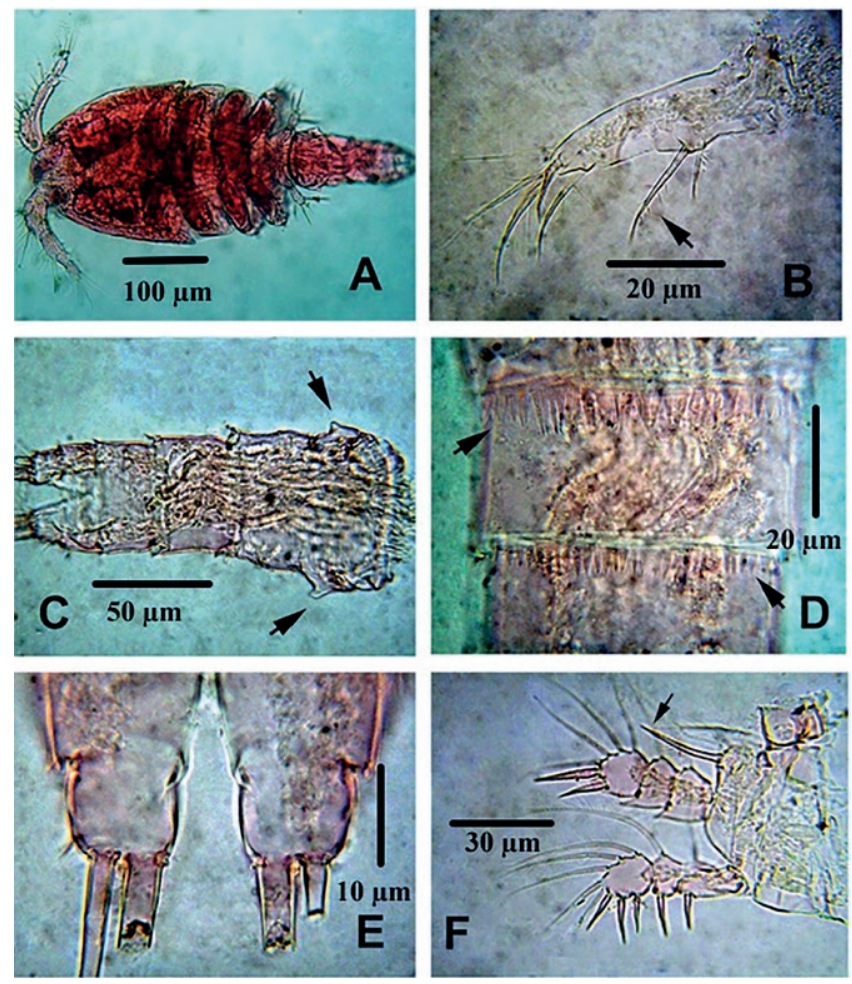

Figure 2. Halicyclops venezuelaensis. Adult female. A. Habitus, B. Maxilliped. C-D. urosome, ventral view. E. Caudal rami. F. P1.
(Fig. 2A); length excluding caudal setae: $616 \mu \mathrm{m}$. It can be easily recognized by a combination of characters including: 1 ) the long proximal seta on the first segment of maxilliped (arrow in Fig. 2B), 2) genital double-somite with lateral protuberances (Fig. 2C, arrowed), 3) ventral margins of urosomites ornamented with large spines (arrows in Fig. 2D), 4) caudal ramus subquadrate, as long as wide (Fig. 2E), 5) inner basipodal spine of P1 (arrow in Fig. $2 \mathrm{~F}$ ) reaching beyond second endopodal segment, 6) P4ENP3 about 1.5 times as long as wide, inner apical spine (arrow in Fig. 3A) slightly longer than segment, 7) P5 EXP about 1.7 times as long wide, innermost spiniform seta (arrow in Fig. 3B) being the longest element of the exopod. The Colombian specimens bear subtle morphological discrepancies with the Belizean specimens reported by Rocha (1995b); in the Colombian populations (Fig. 2F, Fuentes-Reinés et al., 2013, fig. 8D) the inner basipodal spine of P1 almost reaches the insertion point of inner seta of P1ENP3 whereas the same spine is shorter in the Belizean population, reaching the proximal margin of P1ENP2 (Rocha 1995b, fig. 29).

Distribution. This species appears to have a high tolerance to salinity variations, it has been recorded in brackish and freshwater habitats (Rocha 1995b, Fuentes-Reinés et al. 2013, Fuentes-Reinés and Suárez Morales 2015). It has been known to occur in the Venezuelan Caribbean coast, where it was originally described, but also in Belize, Mexico and Colombia (Lindberg 1954, Rocha 1995b, Suárez-Morales and Reid 2003).

\section{Halicyclops hurlberti Rocha, 1991}

(Figures 3C-F, 4, 5)

Material examined. Two adult females (UARC335-343M), Ciénaga Grande de Santa Marta, Colombia, coll. J.M. Fuentes
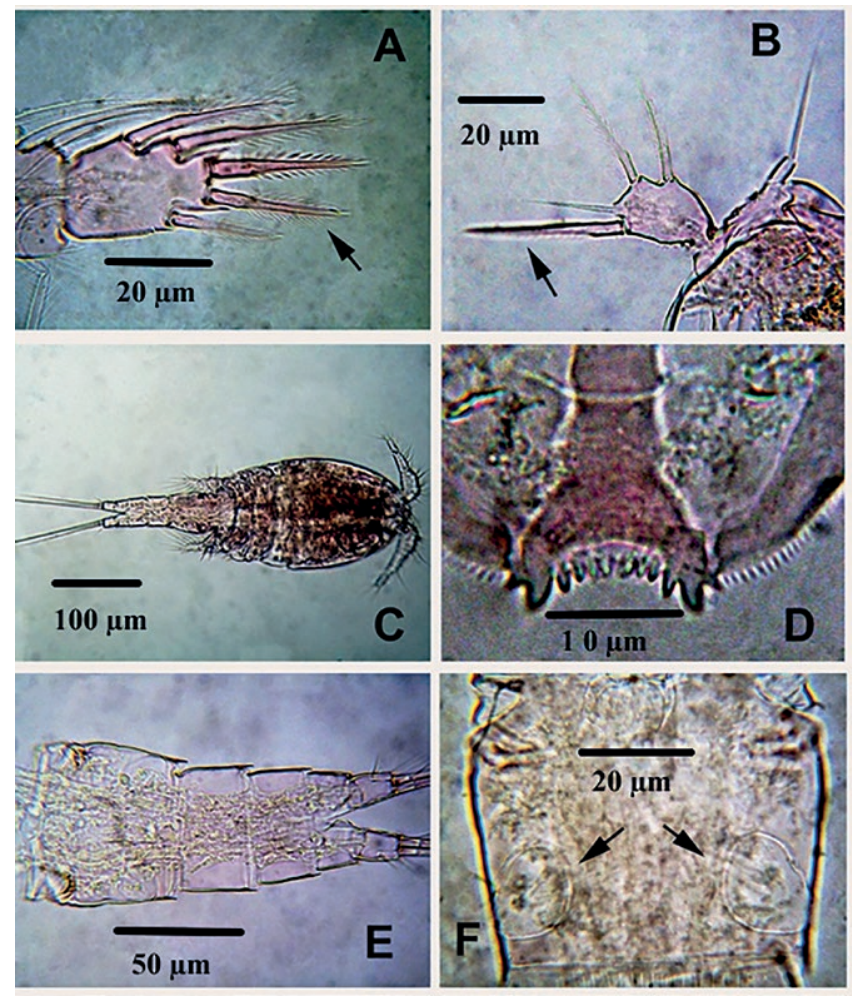

Figure 3. Halicyclops venezuelaensis. Adult female. A. P4ENP3. B. P5. C-F. H. hurlberti, adult female. C. Habitus. D. Labrum. E. Urosome. F. Genital double somite 


\section{Reinés.}

Remarks. The female specimens examined were assignable to $H$. hurlberti following the diagnostic characters presented by Rocha (1991) and Gómez and Rocha (2005). Habitus as in figure 3C, body relatively long, compact anteriorly, cephalosome with large rounded dorsal integumental window and length/ wide ratio $=1.1$. Body length, excluding caudal setae $=588-602$ $\mu \mathrm{m}$ (average $=595 \mu \mathrm{m}, n=2$ ). Labrum with 7-8 small medial teeth set between large lateral teeth (Fig. 3D). Urosome with four segments, genital double somite subquadrate, lacking lateral medial protrusions and with rounded integumental window on each side of posterior half (arrows in Fig. 3F), lateral margins not produced (Fig. 3E-F), caudal rami about 1.4 as long as wide (Fig. 4A), outer seta as long as ramus, dorsal seta (arrow in Fig. 4A) 1.5 times longer than ramus and three times longer than lateral seta, middle inner seta about 2 times as long as middle outer seta, the latter ornamented only with setules (arrow in Fig. 4B)

Antennules 6-segmented, fourth segment 1.6 times as long as wide (Fig. 4C). Antenna consisting of 4 segments (Fig. 4D), coxa reduced, unarmed, basis with two setae at inner corner; seta representing EXP present (arrow in Fig. 4D). ENP 2-segmented. Proximal endopodal segment with single seta on middle inner margin. Length/wide ratio of terminal endopodal segment ratio about 1.9 times as long as wide armed with 5 inner setae and 7 apical setae plus short spinule on proximal outer margin.

P1-P4 EXP and ENP 3-segmented (Figs 4E, F; 5A). Inner basipodal spine of P1 (arrow in Fig. 4E) reaching midlength of P1 ENP3. P2-P3 similar to each other in size and armature (Fig. 4F). P4 ENP3 about 1.6 times as long as wide; inner apical
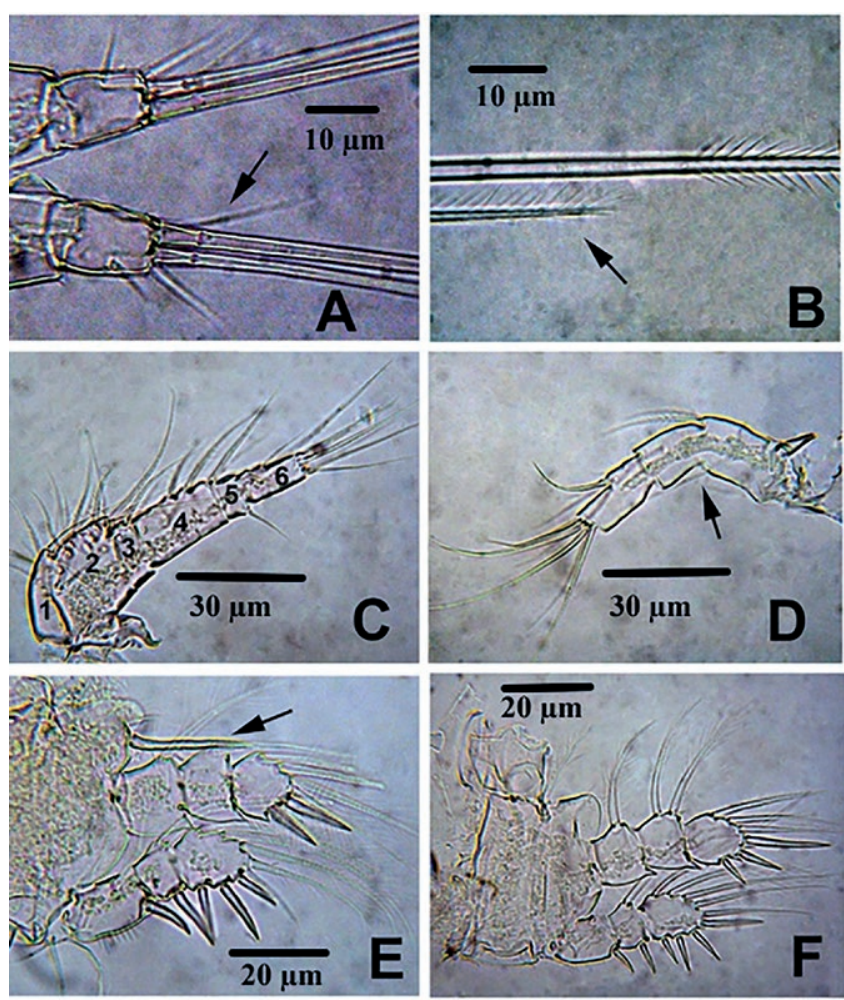

Figure 4. Halicyclops hurlberti, adult female. A. Caudal ramus. B. Setae IV-V of caudal ramus. C. Antennule. D. Antenna. E. P1. F. P2
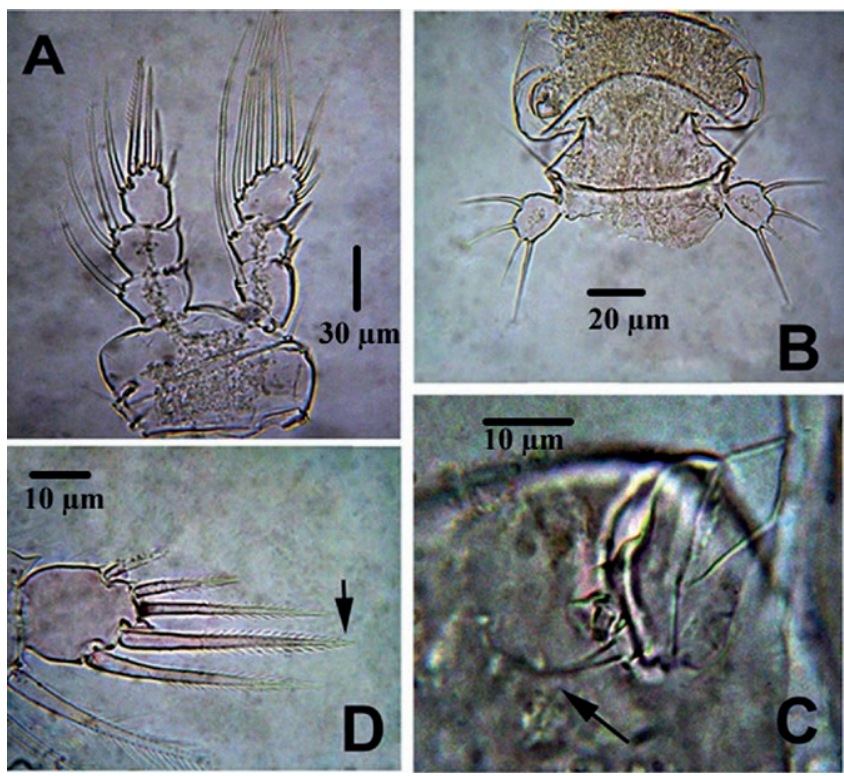

Figure 5. Halicyclops hurlberti, adult female. A. P4, B. P5. C. P6. D. P4ENP3.

spine about 1.6 as long as segment and 1.7 times as long as outer apical spine. Proximal inner seta overpassing the inner apical spine (Fig. 5A). P5 unsegmented, EXP elongate, 1.4 times as long as wide, bearing 3 spines, all of them longer than segment, plus one flexible seta 1.2 times as long as segment (Fig. 5B). P6 represented by a small seta (arrow in Fig. 5C).

Halicyclops hurlberti belongs to the group of species "B" of Halicyclops with a 3443 spine formula but Rocha (1991) recognized a subgroup of species sharing the following characteristics: 1) caudal setae bearing only heteronomously distributed setules, 2) fourth segment of female antennule less than twice as long as wide, 3) inner spine of the second basipodite of P1 reaching at least midlength of P1ENP3. Halicyclops hurlberti is included in this group together with other 13 species: $H$. sinensis, Kiefer, 1928, H. canui Lindberg, 1941, H. pilifer Lindberg, 1949, $H$. blachei Lindberg, 1952, H. crassicornis Herbst, 1955, H. coulli Herbst, 1977, H. laminifer Herbst, 1982, H. glaber Rocha, 1983, H. pilosus Rocha, 1984, H. dussarti Rocha, 1995, H. ramirezi Menu-Marque and Sorarrain, 2007, H. continentalis Ueda and Nagai, 2009, and H. setiformis Ueda and Nagai, 2012. Of these, seven are known from the Neotropical region.

Among the group of species recognized by Rocha (1991), $H$. hurlberti is closest to $H$. coulli but they can be easily distinguished by: 1) the proximal inner seta of P4ENP3 overpasses the inner apical spine in $H$. coulli (Herbst, 1977, Abb. 6) whereas in $H$. hurlberti it is as long as the inner apical spine (Fig. 5D, Rocha, 1991, fig. 6; Gómez and Rocha, 2005, fig. 12A), 2) the distal and proximal inner setae of $\mathrm{P} 4 \mathrm{ENP} 3$ are thicker than the apical spines in $H$. hurlberti (Fig. 5D, Rocha 1991, fig. 6, Gómez and Rocha 2005, fig. 12A) whereas in $H$. coulli they are equally thick (Herbst 1977, Abb. 6), 3) inner basipodal spine of P1 reaching at least midlength of the P1ENP3 in H. hurlberti (Fig. 4E, Rocha 1991, fig. 4, Gómez and Rocha 2005, fig. 11B), whereas in $H$. coulli it reaches the distal margin of P1ENP3 (Herbst 1977, Abb. 5).

The specimens from Colombia show some subtle differences 
with respect to the descriptions by Rocha (1991) and Gómez and Rocha (2005); thus allows an expansion of the morphological knowledge of this species: 1) the caudal rami length/width ratio is about 1.4 in the Colombian specimen while in the Mexican and USA is 1.1 and 1.25, respectively (Rocha 1991, fig. 2, Gómez and Rocha 2005, fig. 2A,C); 2) the two subdistal inner setae of P2-3ENP3 barely reach beyond the distal end of the apical spines in the Colombian specimens (Fig. 2F), whereas in the USA specimens, the inner setae goes well beyond the distal end of the apical spines (Rocha 1991, fig. 5). Overall, we consider that these differences are within the intraspecific range and reveal affinities between the Colombian and Mexican populations.

Among the species known from Colombia, H. hurlberti closely resembles $H$. gaviriai in the following characters: 1 ) they share the same spine formula of P1-P4EXP3; 2) Both of them lack strong processes on the genital double-somite 3) the proximal inner seta of P4ENP3 overpassing tip of inner apical spine, 4) the length/wide ratio of fourth segment of antennule is less than 3 . They can be separated by: 1) the P1 inner basipodal spine reaches the distal margin of P1 ENP2 in $H$. gaviriai (Suárez-Morales and Fuentes-Reinés fig. 2A) whereas in $H$. hurlberti this spine is longer, reaching midlength of P1 ENP3 (Fig. 4E, Rocha 1991 fig 4, Gómez and Rocha 2005, fig. 11B) 2) length/wide ratio which is 1.56 in $H$. gaviriae vs. 1.4 in $H$. hurlberti and relative length of the spines of P5EXP, 3 ) the number of large lateral teeth (1 vs. 2 in H. hurlberti?) of the labrum, 4) the thickness of distal inner spines and apical spines of P4ENP3.

Distribution. Hitherto, Halicyclops hurlberti has been reported only from the Tihuana Estuary in the state of California, in the USA Pacific (Rocha 1991) and from an estuarine system in the state of Sinaloa, in the Mexican Pacific (Gómez and Rocha 2005). Its finding in this area of Colombia represents a geographic range extension of this species from the Eastern Tropical Pacific to the Guajira province sensu Morrone (2014) in the western Caribbean.

Habitat. The northern Ciénaga Grande de Santa Marta is a shallow swamp (depth $0.5-1.5 \mathrm{~m}$ ), with temperature during the sampling period $31.2{ }^{\circ} \mathrm{C}, \mathrm{pH}=8.9$, salinity $=15 \mathrm{PSU}$ and dissolved oxygen $=7.86 \mathrm{mg} / \mathrm{L}$.

\section{Key to the species of Halicyclops belonging to Group "B" sensu Rocha (1991)}

1A. Spine formula 2-3-3-3 H. canui Lindberg, 1941

1B. Spine formula 3-4-3-2

1C. Spine formula 3-4-3-3

1D. Spine formula 3-4-4-3

2A. L/W of the P4ENP3 is about 1-5-1.7, serration of urosomal dorsal frills is almost equally coarse on the second through fourth somites H. setiformis Ueda and Nagai, 2012

2B. L/W of the P4ENP3 is about 1.1, serration of urosomal dorsal frills is very fine on the second and third somites compared to the fourth somite H. blachei Lindberg, 1952

3A. Genital double-somite with round lateral processes, fourth urosomite with squarely produced hyaline frill along the posterodorsal margin H. laminifer Herbst 1982

3B. Genital double-somite with triangular lateral processes, fourth urosomite without squarely produced hyaline frill along the posterodorsal
margin
H. continentalis Ueda and Nagai, 2009

4A. Genital double somite without lateral process 5

4B. Genital double somite with lateral process 6

5A. Spine inserted at inner corner of leg 1 basis of P1ENP goes beyond of P1ENP3, proximal inner seta overpassing the inner apical spine, the proximal and distal setae and the apical spines are equal in thickness H. coulli Herbst 1977

5B. Spine inserted at inner corner of leg 1 basis of P1ENP reaching midlength of P1ENP3, proximal inner seta is as long as the inner apical spine, the proximal and distal inner setae of P4ENP3 are thicker than apical spines H. hurlberti

6A. Caudal ramus divergent H. pilifer Lindberg, 1949

6B. Caudal ramus no divergent

7

7A. P4ENP3 without inner setae

H. glaber Rocha 1983

7B. P4ENP3 with inner setae

8

8A. P4ENP3 inner setae very short, not reaching the midlength of inner apical spine of $\mathrm{P} 4 \mathrm{EN} 3$

9

8B. P4ENP3 inner setae at least reaching midlength or beyond inner apical spine of $\mathrm{P} 4 \mathrm{EP} 3$

10

9A. Posterior margin of genital double somite with larger denticulate hyaline membrane

$$
\text { H. ramirezi Menu Marque and Sorarrain, } 2007
$$

9B. Posterior margin of genital double somite without larger denticulate hyaline membrane H. crassicornis Herbst, 1955

10A. Spine inserted at inner corner of leg 1 basis of P1ENP goes beyond of P1ENP3 H. pilosus Rocha, 1984

10B. Spine inserted at inner corner of leg 1 basis of P1ENP reaching midlength of P1EN3

11A. Urosomites with coarsely serrate frills

H. sinensis Kiefer, 1928

11B. Urosomites with fine serrate frills H. dussarti Rocha, 1995

\section{Acknowledgements}

We are indebted to Dr. Samuel Gómez (Universidad Nacional Autónoma de México, Instituto de Ciencias del Mar y Limnología, Mexico) for kindly providing useful taxonomic literature during the development of this work and for confirming the identification of Halicyclops hurlberti.

\section{Literature cited}

Chang C.Y. 2012. Discovery of Halicyclops continentalis (Cyclopidae, Halicyclopinae) from estuaries and salt marshes on the west coast of South Korea. Animal Systematics, Evolution and Diversity 28: 12-19. http://dx.doi.org/10.5635/ ASED.2012.28.1.012

Collado C., D. Defaye, B.H. Dussart, \& C.H. Fernando. 1984. The freshwater Copepoda (Crustacea) of Costa Rica with notes on some species. Hydrobiologia, 119: 89-99. https://doi. org/10.1007/BF00011948

Defaye D. \& B.H. Dussart. 1988. Compléments à la faune des Crustacés Copépodes des eaux intérieures de Guyane française. Revue d'Hydrobiologie tropicale 21: 109-125.

Fuentes-Reinés J.M. \& E. Suárez-Morales. 2015. Checklist of planktonic copepoda from a Colombian coastal lagoon with record of Halicyclops exiguus Kiefer. Bol. Invest. Mar. Cost, 44(2): 369-389

Fuentes-Reinés J.M., E. Zoppy de Roa \& R. Torres. 2013. Calanoida and Cyclopoida (Copepoda: Crustacea) from Ciénaga Grande de Santa Marta, Colombia. Métodos en Ecología y Sistemática 8(2): 54-103

Gómez S. \& C.E.F. Rocha. 2005. A new species of Kristensenia Por, 1983 and a new record and illustrated supplementary description of Halicyclops hurlberti Rocha, 1991 from Mexico. 
Journal of Natural History, 39(2):133-152. https://doi.org $/ 10.1080 / 00222930410001663320$

Herbst H.V. 1977. Ein neuer Halicyclops aus Nordamerika. Gewasser und Abwasser 62/63: 121-126.

Humes A.G. 1947. A new cyclopoid copepod from a Bornean crustacean. Transactions of the American Microscopical Society 66: 293-301.

Huys R. \& G.A. Boxshall. 1991. Copepod Evolution. The Ray Society, London, $468 \mathrm{pp}$

Karanovic T. 2004. Subterranean Copepoda from arid Western Australia. Crustaceana Monographs 3: 1366.

Kiefer F. 1934. Neue Ruderfusskrebse von der lnsel Haiti. Zool. Anz., 108: $227-233$

Loung T.D., L.D. Minh \& H.T. Hai. 2016. A new species of the genus Halicyclops (Copepoda, Cyclopoida, Cyclopidae) from freshwater in central Vietnam. TAP CHI SINH HOC 2016, 38(4): 449-457. DOI: 10.15625/0866-7160/v38n4.9032.

Morrone J. J. 2014. Biogeographical regionalisation of the Neotropical región. Zootaxa 3282: 1-110. DOI: 10.11646/ zootaxa.3782.1.1

Rocha C.E.F. 1991. A new species of Halicyclops (Copepoda, Cyclopidae) from California, and a revision of some Halicyclops material in the collection of the US Museum of Natural History. Hydrobiologia 226:29-37. https://doi.org/10.1007/ BF00007777

Rocha C.E.F. 1995a. Two new species of Halicyclops (Copepoda, Cyclopoida) from the Amazon Basin, Brazil. Hydrobiologia 315: 167-175. https://doi.org/10.1007/BF00051947

Rocha C.E.F. 1995b. Copepods of the genus Halicyclops (Cyclopidae) from Belize. Hydrobiologia 308:1-11.

Rocha C.E.F. \& T.M. Iliffe. 1993. New cyclopoids (Copepoda) from anchialine caves in Bermuda. Sarsia 78: 43-56. https://doi. org/10.1080/00364827.1993.10413521

Rocha C.E.F., T.M. Iliffe, J.W. Reid \& E. Suárez-Morales. 1998. A new species of Halicyclops (Copepoda, Cyclopoida, Cyclopidae) from Cenotes of the Yucatan Peninsula, Mexico, with identification key for the species of the genus from the Caribbean region and adjacent areas. Sarsia 83: 387-399. https://doi. org/10.1080/00364827.1998.10413698

Rocha, C.E.F., T.M. Iliffe, J.W. Reid \& E. Suárez-Morales. 2000. Prehendocyclops, a new genus of the subfamily Halicyclopinae (Copepoda, Cyclopoida, Cyclopidae) from cenotes of the Yucatan Peninsula, Mexico. Sarsia 85: 119-140. https://doi. org/10.1080/00364827.2000.10414562

Suárez-Morales E. J.M \& Fuentes-Reinés. 2014. A new species of Halicyclops (Copepoda, Cyclopoida, Cyclopidae) from a lagoon system of the Caribbean coast of Colombia. ZooKeys 459: 35-47. https://doi.org/10.3897/zookeys.459.7972

Suárez-Morales E. \& J. W. Reid. 2003. An updated checklist of the continental copepod fauna of the Yucatan Peninsula., Mexico, with notes on its regional associations. Crustaceana 76 (8): 977-992.

Ueda H. \& H. Nagai. 2012. Two new species of Halicyclops (Crustacea: Copepoda: Cyclopidae) from Honshu with a key to the species of the genus in Japan. Species Diversity 17: 97-107.

Walter T.C. \& G. Boxshall. 2017. World of Copepods database. Available at http://www.marinespecies.org/aphia. php? $\mathrm{p}=$ taxdetailsandid $=106433$ on 15 October 2017 